Jurnal Sulolipu : Media Komunikasi Sivitas Akademika dan Masyarakat

Vol. 21 No.12021

e-issn: 2622-6960, p-issn : 0854-624X

\title{
ANALISIS FORMALIN PADA BUAH IMPORT (STUDY LITERATUR)
}

Formaldehyde Analysis On Imported Fruit (Study Literature

\author{
Zaenab1, Ashari Rasjid, Vivi Sri Saputri² $^{2}$ \\ 1,2 Jurusan Kesehatan Lingkungan, Poltekkes Kemenkes Makassar \\ *)zaenab@poltekkes-mks.ac.id
}

\begin{abstract}
Based on the results of this study, it shows that in 7 journals 2014-2018 the research sites in Manado City were positive as many as 18 samples, Medan City was positive as many as 13 samples, Tasikmalaya City was positive as many as 6 samples, Banjarmasin City was positive as many as 6 samples, Kendari City and Makassar City. The formaldehyde content in apples, anngurs and pears changes to a purplish color. Meanwhile, those that do not contain formalin have not changedcolor. Based on the results of the research, it was concluded that imported fruit, namely apples, grapes and pears positively contain formaldehyde. Invite the public to choose local fruits for consumption because it is fresher and healthier, while imported fruits containing formaldehyde because in distribution from the country of origin to Indonesia can last for days, weeks, months.)
\end{abstract}

Keywords : Import fruit, Formalin, Permenkes No. 1168/Menkes/Per/X/1999

ABSTRAK

Berdasarkan hasil penelitian ini menunjukkan bahwa pada 7 jurnal tahun 2014-2018 tempat penelitian di Kota Manado positif sebanyak 18 sampel, Kota Medan positif sebanyak 13 sampel, Kota Tasikmalaya positif sebanyak 6 sampel, Kota Banjarmasin positif sebanyak 6 sampel, Kota Kendari dan Kota Makassar. kandungan formalin pada buah apel, anngur dan pir mengalami perubahan warna keunguan. Sedangkan yang tidak mengandung formalin tidak mengalami perubaha warna. Berdasarkan hasil penelitian disimpulkan bahwa buah import yakni buah apel, anggur dan pir positif mengandung formalin. Mengajak masyarakat agar memilih buah-buahan lokal untuk di konsumsi karena lebih segar dan sehat, sedangkan buah import yang mengandung formalin karena dalam pendistribusian dari Negara asalnya sampai ke Indonesia bisa berlangsung berhari-hari, berminggu-minggu, berbulan-bulan lamanya.

Kata Kunci: Buah Import, Formalin, Permenkes No. 1168/Menkes/Per/X/1999.

\section{PENDAHULUAN}

Bahan pangan ialah salah satu kebutuhan primer manusia supaya bisa menciptakan tenaga. Karbohidrat, lemak, dan protein yang tercantum dalam bahan pangan tersebutlah yang diperlukan manusia buat menunjang proses metabolisme badan. Tidak hanya itu, manusia pula memerlukan vit serta mineral bisa diperoleh dengan komsumsi sayurmayur serta buah- buahan( Cahyo saparinto, Diana Hidayati, 2006).

Fenomena yang terjalin dikala ini, merupakan terdapatnya peredaran buahbuahan import makin menjamur di pasar dalam Negara sebab para distributor serta orang dagang eceren lebih tertarik menjualnya. Membanjirnya buah import dibuktikan dengan Jumlah buah import yang tersebar dalam Triwulan I tahun 2012 berjumlah buah import yang masuk indonesia sebesar 292. 012 ton. Suplai buah impor sangat berlimpah sehingga tidak susah buat memasarkannya. Perihal ini di informasikan oleh Pimpinan Universal Asosiasi Sayur serta buah Indonesia Hasan Johny Widjaja, serta Fenomena menarik, ialah penjualan buah impor dengan memakai kendaraan pick- up( mobil bak terbuka), tersebar banyak di pinggir- pinggir jalur. Bukan cuma itu, peredaran buah import saat ini telah menyebar ke banyak pelosok di Indonesia( Nurchayati. 2014).

Terdapatnya efek tercemarnya buahbuahan oleh formalin yang bisa membahayakan kesehatan konsumen, serta masih terbatasnya pustaka menimpa isi formalin pada buah import.

\section{METODE}

Jenis Penelitian

Adapun Jenis penelitian yang digunakan adalah penelitian yang bersifat studi literatur sumber data yang digunakan dalam penelitian ini berupa data sekunder dari jurnal hasil penelitian yang terpublikasikan dan diperoleh dari internet terkait dengan Analisis formalin pada buah import.

\section{Pengumpulan Data}

Pengumpulan data dalam penelitian ini dilakukan dengan mengumpulkan jurnal-jurnal yang berkaitan dengan analisis formalin pada buah import.

\section{Pengolahan dan Penyajian Data \\ Pengolahan data}

Dilakukan dengan menggunakan alat elektronik berupa handphone, komputer atau laptop 
Jurnal Sulolipu : Media Komunikasi Sivitas Akademika dan Masyarakat

Vol. 21 No.12021

e-issn: 2622-6960, p-issn : 0854-624X

dengan bantuan aplikasi pengolahan data dan angka.

Penyajian Data

Data yang diperoleh dari hasil penelitian akan disajikan secara tekstular/narasi dan dibuat

\section{Analisa Data}

Data hasil yang diperoleh ditabulasikan, kemudian di analisis dengan menggunakan analisis tabel

sintesis GRID (Tabel Sintesis).

HASIL

Tabel 1

Analisis Formalin Pada Buah Import Di Kota Manado

\begin{tabular}{|c|c|c|c|c|c|c|c|}
\hline \multirow[t]{2}{*}{ No } & \multirow{2}{*}{$\begin{array}{l}\text { Lokasi } \\
\text { Sampling }\end{array}$} & \multirow{2}{*}{$\begin{array}{c}\text { Jenis } \\
\text { Sampel }\end{array}$} & \multicolumn{2}{|c|}{ Perubahan Warna } & \multicolumn{2}{|c|}{ Kadar (mg/l) } & \multirow[t]{2}{*}{ Hasil } \\
\hline & & & $\begin{array}{l}\text { Tidak } \\
\text { Dicuci }\end{array}$ & Dicuci & $\begin{array}{c}\text { Tidak } \\
\text { Dicuci }\end{array}$ & Dicuc & \\
\hline \multirow[t]{3}{*}{1.} & Supermarket $A$ & Apel & Kuning & Kuning & 0,195 & 0,111 & Positif \\
\hline & & Pear & Kuning & Kuning & 0,156 & 0,136 & Positif \\
\hline & & Anggur & Kuning & Kuning & 0,075 & 0,075 & Positif \\
\hline \multirow[t]{3}{*}{2.} & Supermarket B & Apel & Kuning & Kuning & 0,136 & 0,075 & Positif \\
\hline & & Pear & Kuning & Kuning & 0,095 & 0,075 & Positif \\
\hline & & Anggur & Kuning & Kuning & 0,085 & 0,060 & Positif \\
\hline \multirow[t]{3}{*}{3.} & Supermarket C & Apel & Kuning & Kuning & 0,095 & 0,080 & Positif \\
\hline & & Pear & Kuning & Kuning & 0,095 & 0,075 & Positif \\
\hline & & Anggur & Kuning & Kuning & 0,080 & 0,060 & Positif \\
\hline
\end{tabular}

Sumber : Glenry Manappo, dkk (2014)

Tabel 2

Analisis Kadar Formalin Pada Buah Import Yang Dijual Di Beberapa Pasar Swalayan Di Kota Medan

\begin{tabular}{lllll}
\hline Kode Sampel & $\begin{array}{c}\text { Nama Buah } \\
\text { Import }\end{array}$ & Negara Asal & Kadar $(\mathbf{m g} / \mathbf{m l})$ & Hasil Analisa \\
\hline Apel 1 & Apel FWS & C & $1,779 \mathrm{mg} / \mathrm{ml}$ & Kadar terendah \\
Apel 2 & Apel BC & A & $2,451 \mathrm{mg} / \mathrm{ml}$ & Positif \\
Apel 3 & Apel GS & A & $1,863 \mathrm{mg} / \mathrm{ml}$ & Positif \\
Apel 4 & Apel HNZ & SB & $1,863 \mathrm{mg} / \mathrm{ml}$ & Positif \\
Apel 5 & Apel FRRC & C & $3,152 \mathrm{mg} / \mathrm{ml}$ & Positif \\
Apel 6 & Apel RD & A & $4,412 \mathrm{mg} / \mathrm{ml}$ & Positif \\
Apel 7 & Apel FJ & J & $4,552 \mathrm{mg} / \mathrm{ml}$ & Kadar tertinggi \\
Anggur 1 & Anggur AR & A & $3,165 \mathrm{mg} / \mathrm{ml}$ & Kadar terendah \\
Anggur 2 & Anggur RG & A & $3,572 \mathrm{mg} / \mathrm{ml}$ & Positif \\
Anggur 3 & Anggur C & A & $4,692 \mathrm{mg} / \mathrm{ml}$ & Kadar tertinggi \\
\hline
\end{tabular}

Sumber : Martha Elnist R. Zalukhu (2015)

Tabel 3

Penetapan Kadar Formalin Pada Buah Import Di Kota Tasikmalaya

\begin{tabular}{lll}
\hline \multicolumn{1}{c}{ Sampel Buah Import } & \multicolumn{1}{c}{ Kadar Sampel (ppm) } & \multicolumn{1}{c}{ Hasil Uji Kualitatif } \\
\hline Anggur hijau & 69,78 & Positif (Ungu) \\
Anggur merah & 784,22 & Positif (Ungu) \\
Pir 1 & - & Negatif \\
Pir 2 & - & Negatif \\
Pir 3 & - & Negatif \\
Apel 1 & 315,33 & Positif (Ungu) \\
Apel 2 & - & Negatif \\
Apel 3 & - & Negatif \\
Apel 4 & - & Negatif \\
\hline
\end{tabular}

Sumber : Tanendri Arrizqiyani (2017) 
Jurnal Sulolipu : Media Komunikasi Sivitas Akademika dan Masyarakat

Vol. 21 No.12021

e-issn: 2622-6960, p-issn : 0854-624X

Tabel 4

Analisis Kualitatif Formalin Pada Buah Apel, Buah Anggur dan Buah Pir Import yang Dijual Dipasar Swalayan Kota Banjarmasin

\begin{tabular}{|c|c|c|c|}
\hline \multirow[t]{2}{*}{ Jenis Sampel } & \multirow{2}{*}{$\begin{array}{c}\text { Jumlah Sampel } \\
\text { (Buah) }\end{array}$} & \multicolumn{2}{|c|}{ Hasil } \\
\hline & & Tidak Dicuci & Dicuci \\
\hline Apel & 6 & 2 positif & 1 positif \\
\hline Pir & 4 & 2 positif & 1 positif \\
\hline Anggur & 4 & 2 positif & 1 positif \\
\hline
\end{tabular}

Sumber : Desy Rahayu Putri (2018)

Tabel 5

Pemeriksaan Formalin Pada Buah Import di Transmart Plaza Medan Fair Kota Medan

\begin{tabular}{llcclc}
\hline No & Jenis Buah Import, Asal & Hasil & Kadar & Warna Yang Dihasilkan & Ket. \\
\hline 1. & Apel Red delicious (Amerika) & Positif & $1,0 \mathrm{mg} / \mathrm{l}$ & Terjadi warna Ungu & TMS \\
2. & Anggur Ungu (Amerika) & Positif & $1,5 \mathrm{mg} / \mathrm{l}$ & Terjadi warna Ungu & TMS \\
3. & Pir (Afrika Utara) & Positif & $0,6 \mathrm{mg} / \mathrm{l}$ & Terjadi warna Ungu & TMS \\
\hline
\end{tabular}

Sumber : Nurul Lailan Najhah (2018)

Tabel 6

Analisis Kandungan Formalin Pada Buah Impor Di Pasar Kota Kendari

\begin{tabular}{lllllllll}
\hline No & Jenis Pasar & \multicolumn{4}{c}{ Apel (Merk Dagang) } & \multicolumn{2}{c}{ Anggur (Asal) } \\
\cline { 3 - 9 } & & Apel A & Apel B & Apel C & Apel D & Apel E & Amerika & China \\
\cline { 3 - 9 } 1. & Lippo Plaza & Negatif & Negatif & Negatif & Negatif & Negatif & Negatif & Negatif \\
2. & Pasar Basah & Negatif & Negatif & - & Negatif & Negatif & Negatif & - \\
3. & Pasar Andonuhu & Negatif & - & - & Negatif & Negatif & Negatif & - \\
4. & Pasar Buah & Negatif & Negatif & Negatif & Negatif & Negatif & Negatif & Negatif \\
5. & Pasar Sentral & Negatif & Negatif & - & Negatif & Negatif & Negatif & - \\
\hline
\end{tabular}

Sumber: Hasriamin, dkk (2017)

Tabel 7

Identifikasi Formalin Pada Buah Import (Apel) Yang Diperjualbelikan Di Kota Makassar

\begin{tabular}{|c|c|c|c|c|c|}
\hline No & $\begin{array}{c}\text { Jenis Buah Import } \\
\text { (Apel), Asal }\end{array}$ & Hasil & Kadar & Warna Yang Dihasilkan & Keterangan \\
\hline 1. & Apel Fuji (Jepang) & Negatif & $0 \mathrm{mg} / \mathrm{l}$ & $\begin{array}{l}\text { Endapan Putih/ Tidak } \\
\text { Terjadi warna Ungu }\end{array}$ & MS \\
\hline 2. & $\begin{array}{l}\text { Apel Grand smith } \\
\text { (Amerika Serikat) }\end{array}$ & Negatif & $0 \mathrm{mg} / \mathrm{l}$ & $\begin{array}{l}\text { Endapan Putih/ Tidak } \\
\text { Terjadi warna Ungu }\end{array}$ & MS \\
\hline 3. & $\begin{array}{l}\text { Apel Re Celicious } \\
\text { (Amerika Serikat) }\end{array}$ & Negatif & $0 \mathrm{mg} / \mathrm{l}$ & $\begin{array}{l}\text { Endapan Putih/ Tidak } \\
\text { Terjadi warna Ungu }\end{array}$ & MS \\
\hline
\end{tabular}

Sumber : Mega Lestari, dkk (2018) 
Jurnal Sulolipu : Media Komunikasi Sivitas Akademika dan Masyarakat

Vol. 21 No.12021

e-issn: 2622-6960, p-issn : 0854-624X

\section{PEMBAHASAN}

Bersumber pada hasil riset diatas, menampilkan kalau bahan kimia beresiko formalin selaku bahan pengawet hidangan yang masih banyak ditemui pada hidangan semacam buah Import. Terdapatnya isi nutrisi, vit serta mineral, buah Import yang tercantum produk yang gampang ataupun cepat busuk. Perihal inilah yang jadi sebab utama sebagian produsen buah Import meningkatkan formalin ke dalam buah import, supaya produsen tidak hadapi kerugian karna buah Import yang di jual tidak habis dalam beberapa hari.

Saat sebelum dicoba analisis kuantitatif formalin pada ilustrasi maka dicoba identifikasi buat mengenali formalin pada ilustrasi dengan pengujian warna ialah dengan tata cara pereaksi Schiff. Pereaksi Schiff digunakan buat mengikat formalin supaya terlepas darisampel. Formalin pula bereaksi dengan pereaksi Schiff menciptakan senyawa lingkungan yang bercorak merah keunguan (Widyaningsih serta Ermi, 2006).

Bersumber pada observasi yangtelah dicoba, ilustrasi buah import dalam keadaan fresh serta kulitnya masih kencang, cuma apel Fuji RRC ialah 3, 153 miligram/ I yang tidak dalam keadaan fresh lagi serta telah tidak kencanglagi. Keadaan tangkai seluruh ilustrasi buah impor dalam kondisi layu serta buahnya apabila dipegang terasa keras. Cuma buah anggur Red Globe yang apabila dipegang terasa lembek dan anggur Calmeria yang apabila dipegang terasa agak lembek.

Bagi Badan Inteligen Negeri Republik Indonesia( 2013) ciri wujud buah berformalin antara lain semacam Permukaan bagian kulit nampak kencang serta fresh mesti sudah berbulan- bulan dipanen ataupun dipajang di supermarket, lapak/ kios/ pasar, tetapi apabila hendak dipegang buahnya terasa keras. Biasanya buah yang diberikan formalin merupakan buah apel serta anggur. Sedangkan buah yang dijual secara bertangkai, bisa ditemui misalnya lengkeng serta anggur, bisa gampang dikenali. Bila tangkai nampak layu, sedangkan buahnya sangat fresh dengan bau menusuk yang bukan buah, mungkin memiliki zat kimia beresiko.

Peninjauan kualitatif dengan memakai respon asam kromatopat diperoleh warna yang ungu tua pada buah Apel. Buah import apel yang dijual di Transmart Plaza Medan Fair dalam keadaan fresh, tidak busuk, tangkainya bercorak coklat serta layu. Buah Import( apel, anggur serta pear diimport dari luar Negara serta memerlukan waktu serta jarak tempuh yang lama buat hingga di Indonesia sehingga digunakan pengawet buat mempertahankan kesegaran supaya buah tidak gampang rusak. Buah- buahan import disemprot dengan formalin buat menewaskan mikroorganisme pada kulit buah sehingga buahbuahan tersebut senantiasa dalam kondisi fresh serta tidak hadapi pembusukan pada buah.

Pembelajaran ke Warga dapat dicoba dengan metode mengantarkan apa yang diartikan dengan formalin, menarangkan akibat serta bahaya untuk kesehatan manusia bila formalin digunakan selaku pengawet santapan ialah buah import, mengujarkan serta mempraktikkan metode memilah buah yang sehat serta bebas formalin dengan mengenali identitas buah yang memiliki formalin semacam karakteristik wujud buah terlihat menarik, warna terang, mengkilap serta lain- lain, mengajak warga supaya memilah buah- buahan lokal buat dikonsumsi karna lebih fresh serta sehat, sebaliknya buah import memiliki pengawet formalin karna dalam pendistribusian dari Negeri asalnya buat hingga di Indonesia dapat berlangsung sepanjang berhari- hari, bermingguminggu ataupun apalagi berbulan- bulan lamanya.

Ada pula identitas buah import yang memiliki formalin pada buah apel, annggur serta pir dapat dilihat dari warna permukaan kulit buah yang memiliki formalin tidak berganti secara signifikan dalam kurung waktu lama ataupun tidak membusuk, warna lebih terang, nampak tidak kumal, nampak lebih menarik, keras kala dipegang, bagian kulitnya nampak kencang serta fresh ataupun kulit luarnya nampak mengkilap walaupun telah berbulan- bulan, tetapi baunya berbeda dengan bau asli buah tersebut, dan buah yang diberi formalin tidak dihinggapi oleh serangga.

Sebaliknya buah yang bebas dari isi formalin dapat dilihat dari buah- buahan yang memiliki formalin hendak terasa lembut serta dikala disentuh serta ditekan, kulit buah nampak nampak natural hendak hadapi pergantian dari hari kehari serta aroma dari buah bebas formalin sangat mengundang serangga kayak lalat, semut serta lebah( Hasriamin, 2017)

Akibat formalin untuk Kesehatan Manusia yang bisa terjalin tergantung berapa banyak kandungan formalin yang terakumulasi dalam badan, terus menjadi besar kandungan yang terakumulasi pasti terus menjadi parah dampaknya. Bila kandungannya dalam tubuh besar, hendak bereaksi secara kimia dengan nyaris seluruh zat didalam seluruh zat didalam sel sehingga menekan peranan sel dengan menyebab kematian sel yang menimbulkan keracunan pada badan. Tidak hanya itu, isi formalin yang besar 
Jurnal Sulolipu : Media Komunikasi Sivitas Akademika dan Masyarakat

Vol. 21 No. 12021

e-issn: 2622-6960, p-issn : 0854-624X

dalam badan pula menimbulkan iritasi lambung, alergi bersifat karsinogenik( menimbulkan kanker) serta bersifat mutagen( menimbulkan pergantian guna sel/ jaringan), dan orang yang mengkonsumsinya hendak muntah, diare bercampur darah, buang air kecil bercampur darah serta kematian yang diakibatkan terdapatnya kegagalan peredaran darah. Formalin apabila menguap di hawa, berbentuk gas yang tidak bercorak, dengan bau yang tajam menyesakkan sehingga memicu hidung, kerongkongan serta mata. Upaya yang wajib dicoba oleh Pemerintah buat menghentikan pemakaian formalin pada pangan ialah mengendalikan peredaran bahan kimia beresiko tercantum bahan pengawet, melaksanakan pengawasan intensif terhadap toko kimia yang menjual formalin, dan pemerintah melaksanakan pembinaan terhadap produsen terpaut bahaya formalin untuk badan.

Pemakaian formalin pada produk hidangan merupakan melanggar peraturan Menteri Kesehatan RI Nomor. 1168/ Menkes/ Per/ X/ 1999 tentang Bahan Bonus Hidangan. Peraturan tersebut secara jelas berkata kalau formalin selaku bahan kimia yang dilarang di pakai dalam santapan. Formalin sangat beresiko bila terhirup, mengenai kulit, serta terisap. Akibat yang dapat ditimbulkan semacam cedera bakar pada kulit, iritasi pada saluran respirasi, respon alergi serta bahaya kanker pada manusia( BPOM, 2003). Bersumber pada hasil pemantauan BPOM tahun 2007 dari 97 contoh santapan yang dijual dipasaran 75, 8\% memiliki formalin( Yuliarti, 2007). Warga Indonesia rata- rata mempunyai hasrat yang besar dalam komsumsi buah- buahan. Buah yang sangat diminati merupakan buah apel, anggur serta pir. Konsumen lebih banyak komsumsi buah import dibanding buah lokal, perihal ini yang jadi pemicu konsumen tidak sangat tergantung pada buah lokal. Rata- rata konsumen mengenali isi buah yang hendak mereka mengkonsumsi beserta asal produksinya. Khasiat dari buah ialah alibi utama konsumen terus setia komsumsi buah- buahan. Sebagian besar konsumen membeli buah di pasar tradisional dengan ketersediaan yang lumayan. Konsumen buah- buahan sebagian besar telah mempraktikkan pola 4 sehat 5 sempurna dengan komsumsi minimun 1 buah per hari per orang buat buah jeruk ataupun minimun 1 buah per hari.
Aspek internal pemakaian pengawet, supermarket di dekat pasar tradisional yang identik dengan buah lokal, permintaan( hasrat) konsumen, penawaran dari agen, hari raya besar/ akhir minggu, serta harga buah. Sebaliknya aspek eksternal merupakan yang pengaruhi energi saing buah import merupakan modal, mutu buah, tampilan( packing) buah, ketersediaan, serta watak buah yang musiman.

Berdasarkan hasil penelitian diatas menunjukkan bahwa buah import yakni apel, anggur dan pir yang dijual dibeberapa pasar dinyatakan positif mengandung formalin, berdasarkan PERMENKES RI Nomor 1168/MENKES/X/1999 Tentang bahan tambahan makanan.

\section{KESIMPULAN}

Kandungan formalin buah import yakni buah apel buah anggur dan buah pir positif mengandung formalin. Sebagaimana telah dibuktikan dengan penelitian - penelitian sebelumnya dalam kurun waktu 5 tahun terakhir.

\section{SARAN}

1. Kepada Masyarakat perlu penyuluhan tentang bahaya formalin dan menganjurkan memilih buah lokal untuk di konsumsi agar memastikan aman dan kurang jejak ekologisnya.

2. Kepada pedagang sebaiknya tidak hanya mendapat keuntungan yang besar tetapi juga memperhatikan aspek kesehatan bagi masyarakat yang mengkonsumsinya seperti dalam membeli buah import perlu memperhatikan kondisi buah tidak hanya dari segi fisik tetapi jika perlu melakukan pemeriksaan pada sampel buah atau bekerja sama dengan BPOM.

3. Disarankan untuk mencuci atau merendam buah sebelum dikonsumsi untuk mengurangi jumlah formalin di dalamannya, selain itu, memasak makanan dengan suhu tinggi dapat juga menurunkan tingkat formalin.

4. Kepada Pemerintah untuk semakinmemperketat pengawasan masuknyabuah import ke dalam Negeri untukmengantisipasi masuknya buahbuahanyang mengandung zat berbahaya seperti formalin. 
Jurnal Sulolipu : Media Komunikasi Sivitas Akademika dan Masyarakat

Vol. 21 No. 12021

e-issn: 2622-6960, p-issn : 0854-624X

\section{DAFTAR PUSTAKA}

Angka dalam Cahyadi. Analisis dan Aspek Kesehatan Bahan Pangan.Bumi Aksara. Jakarta, 2008.

Adiwisastra dalam Cahyadi. Keamanan Pangan.Yogyakarta : Gosyen Publishing, 2008.

Anonimous dan Fadholi. Penyalahgunaan Formalin Sebagai Pengawet Makanan.http://blogspot.com/jurnal-analisis-kualitatif adanya_06.html, diakses tanggal 2 Desember 2010.

Asrianti. Jurnal.Ini Bahaya Formalin pada Makanan. Fakultas Farmasi Universitas Gajah Mada (UGM), 2016.

Cahyadi. Analisi dan Aspek Kesehatan : Bahan Tambahan. Jakarta : Bumi Aksara, 2008.

Cahyadi. Pemeriksaan Formalin Pada Buah Import. Medan : Bumi Aksara, 2009.

Catur Andrianto. Tips Memilih Dan Menyimpan Buah-Buahan.Yogyakarta : Kanisius, 2013.

Desy Rahayu Putri, dkk. Analisis Kualitatif Formalin Pada Buah Apel, Anggur dan Pir Import Yang Dijual di Pasar Swalayan Kota Banjarmasin. Akademik Farmasi ISFI Banjarmasin, 2018.

Effendi, Supli. Teknologi Pengolahan dan Pengawetan Pangan.Alfabet Bandung, 2009.

Fessenden, dalam Cahyadi.Analisis dan Aspek Kesehatan : Bahan Tambahan Makanan. Jakarta: Bumi aksara, 2008.

Glenry Manoppo, Abidjulu, Jemmy. Wehantouw, Frenly. "Analisis Formalin Pada Buah Impor Di Kota Manado". Pharmacon Jurnal IImiah Farmasi-UNSRAT Vol. 3 No.3 Agustus 2014 ISSN 23022493, 2014.

Hamidah, Siti. Sayuran dan Buah serta Manfaatnya Bagi Kesehatan Disampaikan dalam kajian Pengajian Jamaah Langgar Mafaza Kota gede Yogyakarta. Jurnal Fakultas Teknik UNY : Yogyakarta, 2015.

Hasrimin, dkk. Analis Kandungan Formalin pada Buah Import di Kota Kedari. Jurnal Sains danTeknologi Pangan (JSTPUniversitas Halu Oleo) : Kedari, 2017. 